\title{
PENGEMBANGAN SENTRA INDUSTRI TAS DAN KOPER TANGGULANGIN DALAM MENGHADAPI MEA
}

\author{
Gusti Adriansyah', M. Adhi Prasnowo $^{2}$, A. Fathoni Rodli ${ }^{3}$, Khoirul Hidayat ${ }^{4}$ \\ ${ }^{12}$ Program Studi Teknik Industri, Universitas Ma'arif Hasyim Latif \\ ${ }^{3}$ Program Studi Teknik Informatika, Universitas Maarif Hasyim Latif \\ ${ }^{4}$ Program Studi Teknologi Industri Pertanian, Universitas Trunojoyo Madura
}

Email: gustiadriansyah@yahoo.com,prasnowoadhi@dosen.umaha.ac.id, fathoni_rodli@dosen.umaha.ac.id,irul_ie@yahoo.co.id

\begin{abstract}
Small and Medium Enterprises (SMEs) play an important role and strategic for the country's economic growth in both developing and developed countries. At the time of the economic crisis in Indonesia, Small and Medium Enterprises is an economic sector that has the most excellent durability. The ability of SMEs needs to be empowered and developed constantly to try to reduce obstacles experienced by SMEs, so as to provide maximum contribution to improving the welfare of society. Tanggulangin industry is one of the SMEs which stood since 1939 when a few craftsmen begin manufacture of luggage bags and suitcases. And in 1976 founded Bags and Luggage Industry Cooperative (INTAKO), which initially had only 27 people. Venture capital obtained from the principal member. In a way, the cooperative continues to grow and the number of members has reached 354 artisans SMEs with assets of approximately US \$10 billion. Tanggulangin product brand and has had a pretty good quality which has been recognized by consumers. But after the Lapindo mudflow, nearly 70 percent of artisans in Tanggulangin already folded. Some of them are surviving to working order. In addition invasion goods Chinese products very competitive price, but the quality is poor who also took part in the downturn. Practically, bags and suitcases industrial centers deserted visitors. Penelitian Tanggulangin This shows that the cause of the decline in sales is a flood of Chinese products, rising raw material prices, and the lack of innovation in product design. Therefore there is the need for guidance from the government in developing innovation in product design and innovation in marketing. Hence the existence of industrial centers Tanggulangin bags and suitcases can grow and create jobs for local residents as well as increasing revenue Sidoarjo.
\end{abstract}

\section{Keywords: Strategy, Sentra Industries, Bags and Luggage}

\begin{abstract}
Abstrak
Usaha Kecil Menengah (UKM) mempunyai peran penting dan strategis bagi pertumbuhan ekonomi negara, baik negara berkembang maupun negara maju. Pada saat krisis ekonomi berlangsung di Indonesia, Usaha Kecil Menengah merupakan sektor ekonomi yang memiliki ketahanan paling baik. Kemampuan UKM perlu diberdayakan dan dikembangkan secara terus menerus dengan berusaha mereduksi kendala yang dialami UKM, sehingga
\end{abstract}


maтри memberikan kontribusi lebih maksimal terhadap peningkatan kesejahteraan masyarakat. Industri Tanggulangin adalah salah satu UKM yang berdiri sejak 1939 ketika beberapa perajin memulai pembuatan barang-barang tas dan koper. Dan pada tahun 1976 didirikanlah Koperasi Industri Tas dan Koper (Intako), yang awalnya hanya beranggotakan 27 orang. Modal usaha diperoleh dari simpanan pokok anggota. Dalam perjalanannya, koperasi itu terus berkembang dan jumlah anggotanya sudah mencapai 354 perajin UKM dengan aset sekitar Rp 10 miliar. Produk tanggulangin ini telah memiliki brand dan mutu yang cukup bagus yang sudah diakui oleh konsumen. Tetapi setelah terjadi luapan lumpur lapindo hampir 70 persen perajin di Tanggulangin sudah gulung tikar. Beberapa di antara mereka yang masih bertahan hanya untuk menggarap pesanan. Selain itu serbuan barang-barang produk Cina yang harganya sangat kompetitif, namun kualitasnya buruk yang juga ikut andil dalam keterpurukan tersebut. Praktis, sentra industri tas dan koper Tanggulangin sepi pengujung. Penelitian ini menunjukkan bahwa penyebab menurunya penjualan adalah membanjirnya produk cina, kenaikan harga bahan baku, dan kurangnya inovasi desain produk. Oleh karena itu perlu adanya pembinaan dari pemerintah dalam mengembangkan inovasi desain produk dan inovasi dalam pemasaran. Sehingga eksistensi sentra industri tas dan koper Tanggulangin dapat berkembang dan membuka lapangan pekerjaan bagi warga sekitar serta meningkatkan pendapatan asli daerah Kabupaten Sidoarjo.

\section{Kata kunci: Strategi, Sentra Industri, Tas dan Koper}

\section{A. Latar Belakang}

Usaha Kecil Menengah (UKM) mempunyai peran penting dan strategis bagi pertumbuhan ekonomi negara, baik negara berkembang maupun negara maju. Pada saat krisis ekonomi berlangsung di Indonesia, Usaha Kecil Menengah merupakan sektor ekonomi yang memiliki ketahanan paling baik. Kemampuan UKM perlu diberdayakan dan dikembangkan secara terus menerus dengan berusaha mereduksi kendala yang dialami UKM, sehingga mampu memberikan kontribusi lebih maksimal terhadap peningkatan kesejahteraan masyarakat. Industri Tanggulangin adalah salah satu UKM yang berdiri sejak 1939 ketika beberapa perajin memulai pembuatan barang-barang tas dan koper. Dan pada tahun 1976 didirikanlah Koperasi Industri Tas dan Koper (Intako), yang awalnya hanya beranggotakan 27 orang. Modal usaha diperoleh dari simpanan pokok anggota. Dalam perjalanannya, koperasi itu terus berkembang dan jumlah anggotanya sudah mencapai 354 perajin UKM dengan aset sekitar Rp 10 miliar. Produk tanggulangin ini telah memiliki brand dan mutu 
yang cukup bagus yang sudah diakui oleh konsumen. Tetapi setelah terjadi luapan lumpur lapindo hampir 70 persen perajin di Tanggulangin sudah gulung tikar. Beberapa di antara mereka yang masih bertahan hanya untuk menggarap pesanan. Selain itu serbuan barang-barang produk Cina yang harganya sangat kompetitif, namun kualitasnya buruk yang juga ikut andil dalam keterpurukan tersebut. Praktis, sentra industri tas dan koper Tanggulangin sepi pengujung.Dari latar belakang diatas, diperlukan strategi-strategi untuk mengembangkan sentra industri tas dan koper (Intako) Tanggulangin agar eksistensi sentra industri tas dan koperdapat berkembang dan membuka lapangan pekerjaan bagi warga sekitar sertameningkatkan pendapatan asli daerah Kabupaten Sidoarjo.

\section{B. Metode Penelitian}

Penelitian ini menggunakan desain deksriptif. Tujuan desain penelitian deskriptif sebagaimana dijelaskan oleh Sakaran (2008) adalah untuk mendeskripsikan aspek-aspek yang releven dari suatu fenomena yang dipelajari peneliti dari seorang individu, organisasi, industri, atau perspektif lain. Dengan demikian penelitian deskriptif menyajikan data dalam bentuk yang sangat bermakna sehingga membantu untuk memahami karakteristik dari suatu kelompok, membantu dalam pemikiran secara sistimatis tentang aspek-aspek dalam situasi tertentu, menyediakan ide untuk pencarian dan penelitian lebih lanjut, dan membantu dalam pengambilan keputusan. Dalam hal ini konteks yang dipelajari adalah sentra industri tas dan koper (intako) Tanggulangin.Desain penelitian menunjukkan proses penelitian mulai dari perencanaan sampai dengan analisis untuk memperoleh temuan penelitian.

\section{Hasil Dan Pembahasan}

Berdasarkan Industri Tas dan Koper (Intako) merupakan sentra industri yang ada di Tanggulangin Sidoarjo. Sejak turun temurun kerajinan tas dan koper sudah dilakukan oleh masyarakat Desa Kedensari. Sejak 7 april 1976 pengrajin di Desa Kedensari Kecamatan Tanggulangin mendirikan sebuah koperasi dengan nama Koperasi INTAKO (Industri Tas dan Koper) yang beranggotakan 27 orang pengrajin dengan 27 anggota. Jumlah anggota tidak mengalami peningkatan 
sampai tiga tahun, baru pada tahun keempat ada penambahan anggoota menjadi 40 anggota.Dengan adanya koperasi INTAKO banyak pengrajin yang berkaloborasi dalam membuat industri kulit, sehingga omzet penjualan mengalami peningkatan. Dalam membuat sentra industri tas dan koper, dukungan dari para pengrajin sangat besar. Mulai dari pengembangan desain secara bersama, pembelian bahan baku yang terkordinir, serta adanya penentuan harga pasar yang seragam sehingga terciptanya persaingan pasar yang sehat.

Namun sejak terjadinya peristiwa semburan lumpur lapindo yang terjadi pada tahun 2006, pengunjung yang datang ke industri intako menurun drastis. Luapan lumpur telah menghambat akses kendaraan dari arah Malang dan Probolinggo. Sedangkan dari arah Surabaya, akses masih lancar. Akibat dari terjadinya luapan lumpur lapindo yakni hampir 70 persen perajin di Tanggulangin sudah gulung tikar. Beberapa di antara mereka yang masih bertahan hanya beroperasi berdasarkan pesanan saja.Faktor lain yang menyebabkan menurunnya pengunjung industri intako di Tanggulangin ini adalah banyak pemberitaan media massa bahwa luapan lumpur sudah mencapai perumahan tanggulangin anggun sejahtera (Perum TAS) yang mana memunculkan persepsi kepada masyarakat luas bahwa industri Tas di Tanggulangin berada satu kawasan dengan perumahan tersebut. Padahal secara geografis, intako di tanggulangin masih berjarak 5 kilometer dari pusat semburan lumpur Lapindo. Sampai hari ini, sentra industri tas dan koper terbesar di Jawa Timur itu pun sama sekali belum tersentuh pekatnya lumpur.

Daerah Tanggulangin ini termasuk daerah tujuan wisata belanja yang telah ditetapkan Departemen Pariwisata Provinsi Jawa Timur. Tanggulangin masuk daerah Kabupaten Sidoarjo, letaknya sebelah selatan dari arah kota Surabaya jaraknya $20 \mathrm{~km}$ dari Surabaya dan sekitar 30 menit perjalanan dengan kendaraan pribadi, dan berada di sebelah utara dari arah kota Malang. Tanggulangin ini terkenal dengan nama koperasi intako yaitu Koperasi Industri Tas dan Koper, bahkan namanya sudah dikenal sampai manca negara. Banyak pejabat manca negara yang datang untuk membeli produk dari industri kerajinannya.Pada awalnya, produk intako di Tanggulangin yang paling terkenal adalah produk tiruan dari tas merk internasional seperti prada dan gucci. Maka tak heran jika 
banyak produk yang ditawarkan di intako adalah merk internasional yang harganya tidak puluhan juta lagi. Namun setelah ada larangan untuk tidak meniru merk-merk terkenal, maka saat ini pengusaha intako sudah mempunyai merkmerk sendiri.

Bencana lumpur lapindo yang terjadi pada tahun 2006 sangat berdampak pada pertumbuhan intako yang letaknya berdekatan dengan musibah alam lumpur lapindo porong. Tahun 2004, tercatat ada 450 showroom anggota koperasi Intako. Namun, setelah bencana lumpur, hanya menyisakan 150 showroom yang mampu bertahan. Omzet penjualan anggota Koperasi Industri Tas dan Koper (Intako) juga turun hingga 70 persen, dari rata-rata 1,3 miliar menjadi 400 juta per bulan.

Namun perbaikan perekonomian terus dilakukan oleh pemerintah juga koperasi intako yang menaungi mayoritas dari pengusaha industri tas dan koper (Intako) di Tanggulangin. Banyak usaha yang telah dilakukan, salah satunya yakni dengan membuka pasar wisata pada tahun 2011 oleh pemerintah, juga melakukan acara Tanggulangin Fair tahun 2008 dan 2010 dalam penyambutan tahun baru oleh pihak koperasi intako. Tidak hanya pihak luar, pihak pengusaha sendiri juga terus memperbaiki usahanya masing-masing dengan menyambung komunikasi dengan para pelanggan setelah bencana lumpur lapindo, juga melakukan strategi menjemput bola.

Dalam setiap pelaksanaan program tidak akan berjalan dengan mulus, pasti mengalami kendala dan hambatan. Tetapi di sisi lain juga terdapat faktor pendorongnya yang dapat mensukseskan pelaksanaan program. Sehingga diperlukan langkah untuk mengeliminir hambatan dan perlu memikirkan langkah lagi untuk memudahkan pelaksanaan program.Implementasi Rencana Strategi Diskoperindag dalam memberdayakan industri kecil Tanggulangin. Peran Diskoperindag Dalam Mengembangkan industry tas dan koper tanggulangin. Strategi yang sudah dilakukan yaitu ; 1) Pembinaan Desain produk, berdasarkan hasil temuan dilapangan pelaksanaan pembinaan desain produk kurang mendapat perhatian dari Diskoperindag Kabupaten Sidoarjo. Hal ini terbukti dari pembinaan terhadap pengusaha industri kecil tas dan koper cuma terjadi pada waktu itu dan itu pun tidak secara berkelanjutan. 2) Pembinaan Dalam Bidang Promosi, 
sehingga pengusaha industri kecil dapat membuka akses keberbagai peluang dalam pemasaran produknya.

Perkembangan Tingkat Pendapatan Pengusaha Melalui Kegiatan Pemberdayaan Industri Kecil Tas dan Koper dilihat Dari Segi Produksi Program pemberdayaan yang dilakukan Diskoperindag memperoleh hasil yang baik. Dapat dilihat bahwa kenaikan pendapatan para pengusaha industri kecil tas dan koper Tanggulangin naik hingga 20\%. Para pengusaha mengaku dulu penghasilan perbulan hanya 20 juta perbulan setelah adanya pemberdayaan bisa mencapai 40 juta perbulan. Yang paling banyak menyumbang pada penghasilan para pengusaha ialah kegiatan pameran yang gencar dilakukan di dalam maupun luar negeri. Dibukanya arteri tol porong juga sedikit berpengaruh terhadap penghasilan pengusaha.

Faktor-faktor yang menjadi pendukung dan penghambat dari implementasi rencana strategis diskoperindag dalam pemberdayaan industri kecil tanggulangin khususnya pada industri tas dan koper, yang di dalamnya meliputi: (1) Faktor Internal Dari Implementasi Rencana Strategis yang mempunyai faktor Pendukung Antara lain : adanya Rencana Strategis dan Rencana Kerja bagi SKPD yang terkait dengan pemberdayaan industri kecil, meningkatkan pelaksanaan Pembinaan Desain Produk dan Pembinaan Promosi terdapat di Rencana Kerja (Renja), pemerintah yang pro aktif dalam pemberdayaan industri kecil, bantuan berupa mesin jahit kepada pengusaha industri kecil, visi dan misi Dinas Perindustrian, Perdagangan dan ESDM Sidoarjo. menetapkan Visi yaitu “Terwujudnya Sektor Koperasi, Perindustrian, Perdagangan, dan ESDM yang Tangguh dan Mandiri Sebagai Penggerak Ekonomi Rakyat” dengan dukungan Misi sebagai berikut: 1) Meningkatkan Kualitas Aparatur dan Pengelola Perindustrian, Perdagangan. 2) Memberdayakan Ekonomi Masyarakat Perindustrian, Perdagangan. 3) Meningkatkan Kemampuan Usaha Koperasi, UKM, Perindustrian, Perdagangan, dan ESDM. Sedangkan faktor Penghambat antara lain : kurangnya frekuensi pelatihan desain produk kepada pengusaha industri kecil tas dan koper Tanggulangin, banyak pekerja industri kecil Tanggulangin yang keluar dan beralih kepekerjaan lain. 
Faktor Eksternal Dari Implementasi Rencana Strategis yang memiliki faktor pendukung antara lain :undang-Undang No. 20 Tahun 2008 tentang usaha mikro, kecil, dan menengah. Sehingga adanya Pemerintah juga turut berperan aktif dalam pemberdayaan industri kecil, adanya partisipasi pengusaha industri kecil Tanggulangin. c) Visi dan Misi Kabupaten Sidoarjo. 1) Visi Pemerintah Kabupaten Sidoarjo: "Sidoarjo Sejahtera, Mandiri dan Berkeadilan" 2) Misi Pemerintah Kabupaten Sidoarjo: delapan misi utama yang dijalankan secara berkesinambungan dan sinergi, yang memfokuskan pada pengembangan sektorsektor ekonomi dan pengembangan sumber daya manusia sebagai basis pembangunan kemakmuran masyarakat Sidoarjo yang mandiri. Sedangkan faktor Penghambat antara lain : mainset pengusahanya (untuk pengrajin yang kecil pokoknya mendapatkan order) serta jalan yang terlalu sempit, UKM yang masih manja dalam mengikuti berbagai kegiatan promosi.

\section{Penutup}

Produksi Kesimpulan dari penelitian ini menunjukkan bahwa penyebab menurunya penjualan adalah membanjirnya produk cina, kenaikan harga bahan baku, dan kurangnya inovasi desain produk. Oleh karena itu perlu adanya pembinaan dari pemerintah dalam mengembangkan inovasi desain produk dan inovasi dalam pemasaran. Sehingga eksistensi sentra industri tas dan koper Tanggulangin dapat berkembang dan membuka lapangan pekerjaan bagi warga sekitar serta meningkatkan pendapatan asli daerah Kabupaten Sidoarjo.

\section{Daftar Pustaka}

Departemen Perdagangan Republik Indonesia. 2008. Pengembangan Ekonomi Kreatif Indonesia 2025.

Direktorat Penelitian dan Pengabdian Kepada Masyarakat Direktorat Jenderal Pendidikan Tinggi Kemendikbud RI. 2013. Pedoman Penelitian Edisi IX.

F. R. David. 2011. Strategic Management Concepts and Cases. Edisi 10. Pearson Prentice Hall, Upper Saddle River. New Jersey.

Halik, A., Perdana, D., \& Prasnowo, M. A. 2016. Peningkatan Usaha Pengepul Barang Bekas Di Kota Surabaya.JPM17: Jurnal Pengabdian Masyarakat. 2(01).

Prasnowo, M. A., \& Hidayat, K. 2017. Kajian Pemberdayaan Masyarakat Dengan Teknologi Tepat Guna (Produksi Olahan Bambu). 
Prasnowo, M. A., Khomaruddin, A., \& Hidayat, K. 2017. Strategi Pengembangan Sentra Industri Kecil Menengah Produksi Krupuk. Teknika: Engineering and Sains Journal. 1 (1), 17-24.

Sakaran, Uma. 2008. Research Methods for Business: A Skill-Building Approach. Second Edition. New York: John Willey \&Sons.

Sutaryo. 2004. Pengaruh Karakteristik Inovasi terhadap Adopsi Tekonologi Internet oleh UKM. Jurnal ekonomi dan Keuangan, Vol. 2, No.2 (Juni), pp 290.

Soetrisno, N. 1999. Pengembangan UKM, Ekonomi Rakyat dan Penanggulangan Kemiskinan. Jakarta: Publikasi Ilmiah.

Tambunan, Tulus. 2001. Industrialisasi di Negara Sedang Berkembang, Kasus Indonesia. Jakarta: Ghalia Indonesia.

T. Pudjadi, Kristanto, dan A. Tommy. 2007. Analisis untuk Perencanaan Strategi Sistem dan Teknologi Informasi pada PT. Ritrans Cargo. Dipesentasikan pada Seminar Nasional Aplikasi Teknologi Informasi. Yogyakarta: 16 Juni 2007. 